\title{
Kebijakan Pemerintah Papua dalam Pelestarian Tradisi Bakar Batu
}

\author{
Herningsih \\ STKIP Muhammadiyah, Sorong Papua \\ Email: herningsihning068@gmail.com
}

\begin{abstract}
Papua which is geographically located on the eastern tip of Indonesia is an area which has a wealth of not only very abundant natural resources but also cultural traditions diversity and traditional arts. Every ethnic group in the area that was formerly known as Irian Jaya has typical of each traditional art. In order to preserve other cultural and artistic traditions, according to Law Number 21 Year of 2001 concerning Special Autonomy for the Papua Province, the central government gives authority to the Government of Papua to regulate and preserve themselves within the NKRI (The Unitary State of the Republic of Indonesia) framework, including the authority to empower, conserve and develop traditional arts as the cultural identity of the Papuan people such as the tradition of stone burning carried out by the Komunitas Muslim di Bumi Cendrawasih (moslem community in Papua). This paper discusses the policy of the Government of Papua in preserving the stone burning tradition among muslims, traditional arts and the inhibiting and supporting factors in implementing the policy.
\end{abstract}

Keywords: Stone Burning Tradition, moslem community, traditional arts, Papua policy.

\begin{abstract}
Abstrak
Papua yang secara geografis terletak di ujung timur Indonesia merupakan daerah yang tidak hanya memiliki kekayaan sumber daya alam yang sangat berlimpah tapi juga kaya akan tradisi budaya dan kesenian tradisional yang beraneka ragam.Setiap suku bangsa di daerah yang dulu lebih dikenal dengan Irian Jaya ini memiliki ciri khas kesenian tradisional masing-masing. Untuk menjaga dan melestarikan tradisi budaya dan kesenian tradisional lainnya tersebut, sesuai Undang-undang Nomor 21 Tahun 2001 tentang Otonomi Khusus bagi Provinsi Papua,pemerintah pusat memberi kewenangan bagi Pemerintah Papua untuk mengatur dan mengurus diri sendiri di dalam kerangka NKRI, termasuk kewenangan untuk memberdayakan dan melestarikan tradisi serta mengembangkan kesenian tradisional yang merupakan identitas kebudayaan masyarakat Papua. Termasuk tradisi bakar batu yang dilakukan oleh Komunitas Muslin di Bumi Cenderawasih. Tulisan ini membahas tentang kebijakan Pemerintah Papua dalam melestarikan tradisi bakar batu di kalangan umat Islam dan kesenian tradisional serta faktor-faktor penghambat dan pendukung dalam melaksanakan kebijakan tersebut.
\end{abstract}

Kata kunci: Tradisi bakar batu, komunitas Muslim, kesenian tradisional, kebijakan Papua. 
Millatī, Journal of Islamic Studies and Humanities, Vol. 3, No. 2, Des. 2018: 209-225

\section{Pendahuluan}

Undang-undang Nomor 31 Tahun 2004 tentang Pemerintahan Daerah melahirkan berbagai implikasi, yaitu perubahan sosial serta fasilitas yang cukup signifikan melahirkan kesempatan nyata bagi daerah untuk bangkit mengembangkan potensi daerah, membangun daerahnya yang merupakan bagian tak terpisahkan dari Pembangunan Nasional. Menyikapi kondisi tersebut yang didasari pemahaman kebhinnekaan suku, agama, dan budaya yang tersebar ke seluruh pelosok negeri, ${ }^{1}$ setiap daerah memiliki budaya yang berbeda-beda yang mencirikan daerahnya masing-masing.

Beragamnya budaya di Indonesia merupakan wujud warisan Indonesia sebagai negara Bhinneka Tunggal Ika, sebagaimana firman-Nya, yang artinya sebagai berikut:

"Hai manusia, sesungguhnya Kami menciptakan kamu dari seorang laki-laki dan seorang perempuan dan menjadikan kamu berbangsa-bangsa dan bersuku-suku supaya kamu saling kenal-mengenal. Sesungguhnya orang yang paling mulia diantara kamu disisi Allah ialah orang yang paling takwa diantara kamu. Sesungguhnya Allah Maha Mengetahui lagi Maha Mengenal" (QS. al-Hujurat: 13).

Dari ayat tersebut di atas menjelaskan bahwa Sang Pencipta menciptakan hamba-Nya dari suku-suku dan latar belakang yang berbeda-beda.Dengan diciptakan-Nya suku-suku yang berbeda-beda, manusia sebagai hamba-Nya dapat saling mengenal satu sama lain untuk saling menjaga silaturrahmi dan bertawakal kepada-Nya.

Kebudayaan merupakan identitas suatu bangsa yang juga bisa dijadikan bukti bahwa bangsa tersebut memiliki sejarah yang panjang. Selain itu, kebudayaan suatu bangsa juga bisa dijadikan ukuran apakah bangsa tersebut maju atau masih tertinggal. Intinya, kebudayaan adalah simbol kebanggaan suatu bangsa.

Suatu budaya bagi masyarakat pemilik atau pendukungnya memiliki nilai yang amat berharga dalam melangsungkan kehidupannya baik sebagai individu maupun sebagai warga masyarakat. Tanpa budaya, suatu masyarakat tidak memiliki identitas yang jelas. Keberadaannya selain bernilai sebagai simbol identitas juga bernilai sebagai sistem tata kehidupan atau semacam blue-print (cetak biru) yang dijadikan sebagai design for living (desain bagi kehidupan) dalam

${ }^{1}$ Iko Monika, Kebijakan Pemerintah Daerah dalam Pelestarian Kesenian Tradisional di Kota Makassar, Jurnal Government, Volume IV, No. 2, Juli 2011, (Makassar: Universitas Hasanuddin, 2011), hlm. 90. 
bersikap dan bertingkah laku untuk memenuhi berbagai macam kebutuhan hidupnya. Williams (1981) mengemukakan bahwa budaya dilihatnya sebagai keseluruhan cara hidup. Baginya, budaya sebagai makna nilai sehari-hari adalah bagian dari totalitas ekspresif hubungan-hubungan sosial. ${ }^{2}$ Dengan demikian, budaya memiliki nilai yang yang amat penting bagi warga masyarakat pemiliknya.

Karena itu, melestarikan kebudayaan merupakan sebuah kewajiban dan tugas kita semua agar bangsa ini makin maju sesuai dengan yang dicitacitakan oleh para fanding father untuk mencerdaskan kehidupan bangsa. Dalam pandangan Islam, melestarikan seni dan budaya boleh dikerjakan apabila seni membawa manfaat bagi manusia, memperindah hidup dan hiasannya yang dibenarkan agama, mengabadikan nilai-nilai luhur dan menyucikannya, serta mengembangkan dan memperhalus rasa keindahan dalam jiwa manusia, maka sunah Nabi mendukung, tidak menentangnya. Karena ketika itu seni telah menjadi salah satu nikmat Allah yang dilimpahkan kepada manusia. ${ }^{3}$

Menurut Quraish Shihab, dalam konteks seni dan budaya, Al-Qur'an memerintahkan kaum Muslim untuk menegakkan kebajikan, memerintahkan perbuatan makruf dan mencegah perbuatan mungkar. Makruf merupakan budaya masyarakat sejalan dengan nilai-nilai agama, sedangkan munkar adalah perbuatan yang tidak sejalan dengan budaya masyarakat. ${ }^{4}$ Dalam Al-Qur'an dijelaskan sebagai berikut:

"Dan hendaklah ada di antara kamu segolongan umat yang menyeru kepada kebajikan, menyuruh kepada yang ma'ruf dan mencegah dari yang munkar; merekalah orang-orang yang beruntung" (QS. Ali Imran [3]: 104).

Dari ayat tersebut di atas menegaskan bahwa setiap Muslim hendaknya memelihara nilai-nilai budaya yang makruf dan sejalan dengan ajaran agama, dan ini akan mengantarkan mereka untuk memelihara hasil seni dan budaya setiap masyarakat. Apabila terdapat pengaruh yang negatif dapat merusak adat-istiadat serta kreasi seni dari suatu masyarakat, maka sudah seharusnya semua orang mempertahankan makruf yang diakui oleh masyarakatnya, serta membendung setiap usaha dari mana pun datangnya yang dapat merongrong makruf tersebut. ${ }^{5}$ Sebab, Al-Qur'an memerintahkan untuk menegakkan makruf.

2 R. William, Culture (London: Fontana, 1981), hlm. 86.

${ }^{3}$ Nurdin Rismansyah, Perancangan pusat seni tradisi Sunda di Ciamis Jawa Barat: Tema reinterpreting tradition, Tesis, (Malang: UIN Maulana Malik Ibrahim, 2014), hlm. 5.

${ }^{4}$ http://media.isnet.org/

${ }^{5}$ Ibid. 
Millatī, Journal of Islamic Studies and Humanities, Vol. 3, No. 2, Des. 2018: 209-225

Salah satu daerah di Indonesia yang memiliki tradisi kebudayaan yang beraneka ragam adalah Provinsi Papua, di mana masing-masing suku bangsa di Bumi Cenderawasih memiliki tradisi masing-masing. Papua adalah provinsi yang secara geografis berada di ujung timur Negara Kesatuan Republik Indonesia. Provinsi Papua berbatasan dengan Papua New Guinea di sebelah timur, sedangkan di sebelah barat berbatasan dengan Provinsi Papua Barat. Sebelah utara Papua ada Samudera Pasifik, dan di sebelah selatan adalah Laut Arafura. Penduduk Pulau Papua adalah ras Melanesia dan pendatang. Papua memiliki potensi besar sebagai daerah wisata. Keunikan budaya antara lain terdapat dalam arsitektur tradisional, seni ukir, alat musik, alat perang, perabotan tradisional, dan lain sebagainya. ${ }^{6}$

Tradisi kebudayaan Papua sendiri pernah diteliti oleh orang-orang asing dengan pembagian wilayah kesenian sesuai dengan hasil penemuan mereka. Dalam "Papua Kunst in Het Rijks Museum", kesenian Papua dibedakan menjadi enam ragam seni yang terdiri dari: (1) Ragam seni Teluk Yos Sudarso; (2) Ragam seni daerah Sentani dan Tanah Merah; (3) Teluk Cenderawasih sampai Pantai Selatan Sorong; (4) Ragam seni daerah Marind-Anim di daerah Merauke; (5) Ragam seni di daerah Asmat; dan (6) Ragam seni di daerah Mimika dan sekitarnya. ${ }^{?}$

Berbicara tentang beraneka ragamnya tradisi kebudayaan Papua dengan ciri khas masing-masing di setiap suku bangsa tidak terlepas dari banyaknya etnik atau suku di Bumi Cenderawasih. Menurut para peneliti, Papua dan Papua Barat memiliki kurang lebih 250-an etnik/suku bangsa. Hal ini memberikan kepada kita bahwa kesenian orang Papua terdiri dari beraneka ragam jenis dan bentuk dengan ciri khas masing-masing/ suku bangsa pemiliknya.

Selain itu, jenis dan karakteristik kesenian tradisional Papua juga dipengaruhi oleh kondisi alam. Kondisi alam Papua terdiri dari 4 zona, yaitu: ${ }^{8}$ Zona rawa, pantai, dan sepanjang aliran sungai; meliputi daerah Asmat, Jagai, Marind-anim, Mimika, dan Waropen; Zona dataran tinggi; meliputi orang Dani, Ngalun, dan orang Ekari/Mee; Zona kaki gunung dan lembah-lembah kecil;

${ }^{6}$ Irfa'ina Rohana Salma, dkk, Piranti Tradisi dalam Kreasi Batik Papua, Dinamika Kerajinan dan Batik, Vol. 34, No. 2, Desember 2017, hlm. 64.

7 Enos H. Rumansara, Memahami Kebudayaan Lokal Papua: Suatu Pendekatan Pembangunan yang Manusiawi di Tanah Papua, Jurnal Ekologi Birokrasi, Vol. 1, No. 1, Februari, (Jayapura: Universitas Cenderawasih, 2015), h. 54.

${ }^{8}$ Enos Rumansa, Peran Sanggar Seni dalam Menunjang Kegiatan Bimbingan Edukatif pada Pameran Benda Budaya Koleksi Museum-museum di Papua, Jurnal Antropologi Papua, Vol. 1, No. 1, 3 April 2003, hlm. 77. 
meliputi daerah Sentani, Nimboran, Ayamaru, dan orang Muyu; dan Zona dataran rendah dan pesisir; meliputi Sorong sampai Nabire, Biak, dan Yapen.

Melihat kekayaan kesenian tradisionalyang sangat berlimpah tersebut, Papua memiliki potensi yang sangat besar, di antaranya dari segi pariwisata demi menopang kehidupan masyarakat pemiliknya ke arah yang lebih sejahtera. Namun, seiring dengan tuntutan dunia global, pewarisan tradisi-tradisi untuk menopang dan mempertahankan kolektivitas sosial memang mengalami hambatan yang signifikan. Salah satu penghambat proses pewarisan tradisi di era pascamodernitas adalah memudarkan identitas kultural yang selama ini melekat pada diri masyarakat pendukung. Persoalan yang mengemuka dalam perkembangan karya seni di era pascamodernitas ini lebih mengacu pada fenomena pertentangan antara isu-isu identitas kultural dengan otonomi karya seni. Diterminasi teknologi komunikasi dan globalisasi media terhadap kesenian tradisional telah mengubah cara pandang masyarakat sehari-hari selama ini mengembangkan tradisi untuk mempertahankan kolektivitas sosialnya. ${ }^{9}$

Di sinilah diperlukan peran Pemerintah Papua dalam menjaga, melestarikan, dan mengembangkan tradisi yang sangat kaya dan bermacam-macam itu.Salah satu tradisi yang masih dipertahankan oleh masyarakat Papua adalah tradisi bakar batu.Mereka tetap memelihara tradisi bakar batu yang merupakan warisan nenek moyang mereka. Bagi masyarakat yang memeluk agama Kristen, daging yang dimasak adalah daging babi. Dan bagi pemeluk Islam, daging babi tersebut diganti dengan daging ayam atau daging hewan lain yang halal menurut Islam.

Selain tradisi bakar batu, masih banyak tradisi-tradisi lain yang juga dipertahankan dan dilestarikan oleh masyarakat Papua, seperti tradisi potong jari, tari-tarian tradisional, mengukir, dan tradisi-tradisi lainnya.

Penjelasan tentang Undang-undang Nomor 21 Tahun 2001 yang menyebutkan otonomi khusus bagi Provinsi Papua pada dasarnya adalah pemberian kewenangan yang lebih luas bagi provinsi dan rakyat Papua untuk mengatur dan mengurus diri sendiri di dalam kerangka Negara Kesatuan Republik Indonesia. Kewenangan yang lebih luas berarti pula tanggung jawab yang lebih besar bagi provinsi dan rakyat Papua untuk menyelenggarakan pemerintahan dan mengatur pemanfaatan kekayaan alam di Provinsi Papua untuk sebesar-besarnya

9 C. Pereira, Religious Dances and Tourisme: Perceptions of The 'Tribal' as the Repository of the Tradisional in Goa, India. Etnografica. Revista do Centro em Rede de Investigacao em Antropologia, 21, 2017, hlm. 125-152. 
Millatī, Journal of Islamic Studies and Humanities, Vol. 3, No. 2, Des. 2018: 209-225

kemakmuran rakyat Papua sebagai bagian dari rakyat Indonesia sesuai dengan peraturan perundang-undangan. ${ }^{10}$ Kewenangan ini juga berarti pemberdayaan dan pelestarian tradisi kebudayaanyang beraneka ragam demi menjaga warisan nenek moyang mereka serta mendongkrak pariwisata Bumi Mutiara Hitam yang sangat potensial.

Kebijakan Pemerintah Papua ini bukan hanya berlaku bagi tradisi-tradisi kebudayaan yang berpotensi mendongkrak pariwisata Papua, seperti kesenian tradisional yang sudah dikenal oleh khalayak, seperti tari-tarian, seni ukir suku Asmat, festival, budaya, dan lainnya. Tapi tradisi yang masih dilakukan atau dilestarikan oleh kelompok minoritas juga tidak lepas dari peran Pemda Papua melalui dinas kebudayaan dan pariwisata melestarikan tradisi tersebut. Salah satu tradisi yang masih bertahan dan dilestarikan tersebut adalah tradisi bakar batu yang masih dilakukan, dipertahankan, dilestarikan oleh Komunitas Muslim di Papua.

\section{Metode Penelitian}

Metode yang digunakan dalam penelitian ini adalah deskriptif dengan teknik pengumpulan data studikepustakaan (membaca buku, majalah, surat kabar, dokumen-dokumen, undang-undang, serta media informasi lain yang ada hubungannya demgan yang diteliti).Selain itu peneliti juga melakukan observasi, yaitu mengamati obyek yang diteliti dengan tujuan untuk mendeskripsikan gambaran riil di lapangan tentang kondisi atau keadaan tradisi bakar batu yang masih dilakukan oleh Komunitas Muslim dan kesenian tradisional lainnya serta pelaksanaan kebijakan Papua dalam upaya melestarikan tradisi kebudayaan tersebut. Dan melakukan interview dan wawancara dengan para informan, yakni masyarakat Papua (pelaku seni), warga Muslim, pejabat setempat, dan wisatawan.

\section{Hasil dan Pembahasan}

\section{Kebijakan Pemerintah Papua dalam Melestarikan Tradisi Bakar Batu Komunitas Muslim}

Berdasarkan peraturan menteri 42 tahun 2009 dan 40 tahun 2009 pelestarian adalah upaya perlindungan pengembangan dan pemanfaatan kebudayaan yang dinamis. Filosofi pelestarian didasarkan pada kecenderungan manusia untuk

10 Hari Suroto, Pelestarian Sumberdaya Budaya dalam Bingkai Otonomi Khusus Papua, Jurnal Papua Vol. 1 Nomor 1, Juni 2009, hlm. 25. 
melestarikan nilai-nilai budaya pada masa yang telah lewat namun memiliki arti penting bagi generasi selanjutnya.

Upaya melestarikan suatu kebudayaan tradisi bukan hanya merupakan tugas masyarakat pemilik kebudayaan tersebut, tapi juga merupakan tugas semua stakeholder dan Pemerintah Pusat serta Pemerintah daerah dalam menjaga dan melestarikannya. Dalam konteks pelestarian kebudayaan Papua, Pemerintah Daerah Papua membuat beberapa kebijakan dalam rangka menjaga dan melestarikan tradisi kebudayaan Papua.

Kebijakan Pemerintah Daerah Papua bukan hanya melindungi, menjaga, dan melestarikan tradisi kebudayaan yang berpotensi mendongkrak pariwisata Papua, seperti kesenian tradisional yang sudah dikenal oleh khalayak, seperti tari-tarian, seni ukir suku Asmat, festival, budaya, dan lainnya. Tapi kebijakan tersebut juga berlaku bagi tradisi-tradisi yang dilakukan oleh Komunitas Muslim yang merupakan kelompok minoritas di Bumi Mutiara Hitam.

Hal tersebut berlandaskan pasal 5 ayat (2) UU No. 21 Tahun 2001 tentang Otonomi Khusus bagi Provinsi Papua, yang selanjutnya disebut MRP (Majelis Rakyat Papua) dan resmi dibentuk pada tahun 2005,yang berbunyi: ${ }^{11}$ Dalam rangka penyelenggaraan otonomi khusus di Provinsi Papua dibentuk Majelis Rakyat Papua yang merupakan representasi kultural orang asli Papua dengan berlandaskan pada penghormatan terhadap adat dan budaya, pemberdayaan perempuan, dan penetapan kerukunan hidup beragama.

Teori keadilan menjelaskan bahwa keadilan merupakan suatu tujuan hukum yang hendak dicapai guna memperoleh kesebandingan di dalam masyarakat. Selain itu juga untuk kepastian hukum dan kemanfaatan. Menurut Soerjono Soekanto, masalah keadilan merupakan persoalan rumit yang sering dijumpai hampir pada setiap masyarakat, termasuk di Indonesia. Keadilan selalu berkaitan dengan hukum, misalnya seseorang merasakan adanya keadilan jika hukum itu benar-benar ditegakkan. ${ }^{12}$ Berkaitan dengan penulisan ini, yaitu agar tercipta rasa aman dan adil dalam masyarakat Papua, khususnya dalam melaksanakan tradisi yang dilakukan oleh kelompok minoritas di Papua.Salah satu tradisi yang masih dipertahankan oleh umat Islam di Papua tersebut adalah tradisi bakar batu.

Tradisi bakar batu merupakan salah satu tradisi penting di Papua yang berupa ritual memasak bersama-sama warga satu kampung yang bertujuan

${ }^{11}$ Undang-undang No. 21 Tahun 2001 tentang Otonomi Khusus bagi Provinsi Papua.

${ }^{12}$ Soerjono Soekanto, Pengantar Penelitian Hukum, (Jakarta: UI Press, 2007), hlm. 169. 
Millatī, Journal of Islamic Studies and Humanities, Vol. 3, No. 2, Des. 2018: 209-225

untuk bersyukur, bersilaturahim (mengumpulkan sanak saudara dan kerabat, menyambut kebahagiaan (kelahiran, perkawinan adat, penobatan kepala suku), atau untuk mengumpulkan prajurit untuk berperang. Tradisi Bakar Batu umumnya dilakukan oleh suku pedalaman/pegunungan, seperti di Lembah Baliem, Paniai, Nabire, Pegunungan Tengah, Pegunungan Bintang, Jayawijaya, Dekai, Yahukimo dll. Disebut Bakar Batu karena benar-benar batu dibakar hingga panas membara, kemudian ditumpuk di atas makanan yang akan dimasak. Namun di masing-masing tempat/suku, disebut dengan berbagai nama, misalnya Gapiia (Paniai), Kit Oba Isogoa (Wamena), atau Barapen (Jayawijaya). ${ }^{13}$

Dalam tradisi asal, tradisi bakar batu menggunakan daging babi, namun karena ini dilaksanakan oleh warga Muslim Papua, maka daging babi tersebut diganti dengan daging ayam. Seperti tradisi masyarakat suku lainnya di Indonesia, tradisi bakar batu ini dilakukan secara gotong royong. Para lelaki dan perempuan terlibat aktif di dalamnya. Namun para perempuanlah yang terlibat penuh hingga berakhirnya acara bakar batu ini. Kaum lelaki mendapat peran menyiapkan kayu bakar, sedangkanpara perempuan yang mengawal proses tradisi ini hingga akhir. ${ }^{14}$

Setelah batu yang dibakar tersebut sudah mulai membara, para mama mulai mengambil dan menaruh batu-batu panas itu di atas tumpukan ilalang dan rerumputan lainnya. Lalu menutupnya lagi selapis demi selapis. Di antara lapisan itulah beragam sayur-mayur dan umbi-umbian diletakan, sampai matang. Sesekali, tumpukan batu panas, rerumputan dan sayur-mayur itu disiram air dingin agar merangsang uap panas untuk membuat bahan-bahan makanan tadi tanak. Setelah itu, batu panas kembali diletakan dan ditimbun dengan ilalang dan rerumputan lain. ${ }^{15} \mathrm{Nah}$, ditumpukan paling ataslah daging ayam diletakan, kemudian ditutupi ilalang lagi dan tindih dengan batu panas.

Menurut Abu Hanifah Asso, anak lelaki dari kepala suku Tahuluk Asso, yang selama ini berperan mewakili bapaknya memimpin acara-acara tradisi seperti ini, meski sudah memeluk agama Islam, tradisi asli mereka tak mungkin ditinggalkan. menurutnya, ini adalah memelihara tradisi tapi tetap menjaga akidah. Dan bagi Abu Hanifah, itu adalah harga mati ketika mereka sudah memeluk Islam. Dan warga lainnya, sungguh menghormati keyakinan mereka itu. ${ }^{16}$

${ }^{13}$ Untuk lebih lengkapnya, baca https://id.wikipedia.org/wiki/Bakar_Batu (Diakses pada 15 Oktober 2018).

14 Jafar G.Bua, Tradisi Bakar Batu Muslim Papua: Memelihara Tradisi, Menjaga Akidah, www.kompasiana.com, edisi 24 Juni 2015 (Diakses pada 15 Oktober 2018).

${ }^{15} \mathrm{Ibid}$.

${ }^{16}$ Ibid. 
Biasanya, tradisi bakar batu yang dilakukan oleh Komunitas Muslim ini diselenggarakan setiap tahun dalam rangka menyambut bulan suci Ramadhan dan juga saat Hari Raya Idul Fitri. Di Jayapura sendiri ada sekitar 650 warga Muslim asal Wamena, yang berada di Papua sejak tahun 1981. Namun, belum dapat dipastikan, sejak kapan tradisi bakar batu ini dilakukan oleh mereka (Komunitas Muslim). Yang jelas, tradisi ini dilindungi oleh Pemda setempat sesuai dengan Peraturan Daerah Provinsi Papua, Nomor 16, Pasal 2 dan Pasal 4, Tahun 2008 tentang Perlindungan dan Pembinaan Kebudayaan Asli Papua.

\section{Kebijakan Pemerintah Daerah Papua dalam Melestarikan Kesenian Tradisional}

Selain tradisi bakar batu yang masih dilaksanakan oleh Komunitas Muslim di Papua,tradisi kebudayaan lain yang juga dipertahankan dan dilestarikan oleh Pemerintah Daerah Papuamelalui kebijakan-kebijakan yang dikeluarkannya. Hal ini sesuai dengan Peraturan Daerah Provinsi Papua, Nomor 16, Pasal 2 dan Pasal 4, Tahun 2008 tentang Perlindungan dan Pembinaan Kebudayaan Asli Papua. Kebijakan-kebijakan tersebut di antarnaya adalah sebagai berikut:

\section{Pelaksanaan Pemberdayaan Sanggar-sanggar Kesenian}

Pemerintah Papua melalui Dinas Pariwisata dan Kebudayaan melaksanakan pembinaan terhadap sanggar-sanggar kesenian di Papua yang tidak terhitung jumlahnya. Selain itu memberikan fasilitas dan sarana-prasarana seperi alat musik, baju tradisional, dan seperangkat 'alat' seni lainnya yang menunjang terhadap kreasi seni sanggar-sanggar tersebut. Pemerintah Papua juga membantu sanggar-sanggar seni tersebut untuk mengikutsertakan dalam acara-acara kesenian seperti festival budaya dan evel lainnya;

\section{Mempromosikan Produk-produk Kesenian Tradisional}

Pemerintah Papua melalui Dinas Pariwisata dan Kebudayaan mempromosikan produk-produk kesenian tradisional khas masing-masing suku bangsa di Papua seperti ukiran khas Suku Asmat, Noken, batik tulis khas Suku Dhani, dan produk-produk kesenian tradisional lainnya. Adapun cara yang dilakukan Pemda Papua dalam mempromosikan produk-produk kesenian tradisional tersebut, di antaranya adalah melalui sosial media (Instagram, Facebook, Twitter).

Promosi melalui media sosial tersebut dilakukan karena Pemda Papua sadar bahwa di dunia digital saat ini sosial media merupakan salah satu cara yang 'ampuh' dalam mempromosikan sesuatu, karena masyarakat dari berbagai macam 
Millatī, Journal of Islamic Studies and Humanities, Vol. 3, No. 2, Des. 2018: 209-225

kalangan aktif di sosmed.Intinya, Pemda Papua ingin memanfaat kecanggihan teknologi informasi secara maksimal.Dengan mempromosikan hasil produksi kesenian tradisional, Pemerintah Papua berharap kehidupan masyarakat Papua lebih sejahtera dan mereka semakin produktif dalam berkarya. Dengan cara ini, masyarakatPapua merasa karya mereka diapresiasi oleh pemerintah, sehingga mereka lebih produktif dan semangat dalam membuat atau mencipta;

\section{Menjadi Mediator}

Pemerintah Papua memediasi masyarakat (pelaku seni) untuk mendapatkan kucuran dana baik dari instansi pemerintah maupun swasta dalam melestarikan kesenian tradisional. Hal ini dilakukan dalam rangka meningkatkan kesejahteraan masyarakat dan sebagai modal baik dalam memproduksi maupun mempromosikan produk-produk kesenian tradisional mereka.

Mengenai bantuan dari instansi non pemerintah (swasta), pemerintah (pusat) mempunyai kebijakan, yaitu membantu masyarakat yang ingin mengembangkan potensi pariwisata di daerah tertentu, dalam hal ini kesenian tradisional, untuk mendapatkan bantuan dana dari instansi swasta. ${ }^{17}$ Dinas Kebudayaan dan Pariwisata Pemerintah Papua memberi himbauan atau pengarahan kepada setiap kabupaten atau suku bangsa di daerah yang juga terkenal dengan Tari Sajojonya ini untuk melaksanakan pembinaan masyarakat pariwisata (kesenian tradisional), yaitu dengan mengajarkan masyarakat untuk mengembangkan potensi kepariwisataan yang di masing-masing kabupaten atau suku bangsa tersebut.

\section{Membangun Museum dan Taman Budaya}

Pemerintah Papua membangun Taman Budaya dalam rangkamelestarikan seni budaya Papua. Taman ini berlokasi di Jayapura, tepatnya di daerah Wamena. Adapun tujuan Pemerintah Papua membangun taman yangmulai dibangun pada awal 1980-an ini yaitu dengan harapan dapat menjadi pusat kesenian dan kebudayaan Papua.Di tempat ini, Pemerintah Papua memberi ruang seluas-luasnya bagi para pelaku seni Papua untuk mengekspresikan karya-karya. Bahkan pagelaran atau festival budaya juga digelar di taman ini sebelum dipindahkan ke lapangan PTC Entrop, salah satu kawasan yang menjadi pusat perdagangan di Kota Jayapura.

Selain membangun museum, Pemerintah Papua juga membangun museum, yaitu Museum Negeri Provinsi Papua.. Museum yang dibangun bersamaan

${ }^{17}$ Iko Monika, Kebijakan Pemerintah Daerah dalam Pelestarian Kesenian Tradisional di Kota Makassar, Opcit, hlm. 92. 
dengan Taman Budaya Papua pada 1982 hingga diresmikan penggunaannya pada 1984 ini memiliki fungsi, yakni sebagai lembaga pendidikan dan studi wawasan budaya bangsa serta pusat informasi yang bersifat edukatif cultural Papua.

Museum yang dirintis sejak awal tahun 1980-an oleh Kepada Bidang Permuseuman, Sejarah dan Kepurbakalaan Departemen Pendidikan dan Kebudayaan Perwakilan Papua, ini memiliki 3.619 koleksi benda budaya yang didapat dari berbagai daerah di Provinsi Papua dan Papua Barat. Di mana di dalamnya terdapat koleksi seni rupa dan ukiran-ukiran karya manusia Papua. Tercatat sebanyak 15.700 jenis ukiran dari 250 suku di Papua yang terpajang di museum tersebut.

\section{Mengadakan Festival Budaya}

Kebijakan Pemerintah Papua selanjutnya dalam upaya melestarikan kesenian tradisional yaitu mengadakan festival budaya yang diselenggarakan setiap tahun. Beberapa fesitval yang diselenggarakan setiap tahunnya tersebut adalah Festival Budaya Asmat, Festival Lembah Baliem, dan Festival Noken. Tujuan dari diselenggarakannya festival-festival ini, selain untuk melestarikan seni budaya etnik yang ada, juga untuk mengetahui peta perkembangan kesenian tradisional Papua guna mewujudkan masyarakat budaya dan pariwisata Papua yang lebih baik, bermanfaat, dan maju.

Melalui festival-festival ini, peserta dari luar diminta hadir dan melihat sendiri proses dan latar belakang seni budaya Papua sehingga mereka bisa menghargai produk kesenian tradisional dengan lebih baik. Sesungguhnya festival-festival yang biasanya selalu dipadati oleh para wisatawan setiap penyelenggaraannya ini merupakan acara yang diperuntukkan bagi masyarakat pemilik tradisi itu untuk melakukan aktivitas mencipta, menggali, melestarikan, mengembangkan, dan melindunginya. ${ }^{18}$ Dan ini berarti masyarakat diberi kesempatan dan peran sebesar-besarnya untuk melakukan upaya pelestarian seni budaya Papua.

\section{Faktor Pendukung dan Penghambat dalam Pelestarian Kebudayaan Papua}

Pemerintah Daerah Papua dan Komunitas Muslim dalam melaksanakan pelestarian tradisi bakar batu, tentu tidaklah berjalan dengan mudah. Mereka mendapatkan banyak sekali hambatan dan rintangan dalam melestarian tradisi

${ }^{18}$ Hari Suroto, Pelestarian Sumberdaya Papua dalam Bingkai Otonom Khusus Papua, Jurnal Papua, Vol. 1 No. 1 Juni 2009, hlm. 27. 
Millatī, Journal of Islamic Studies and Humanities, Vol. 3, No. 2, Des. 2018: 209-225

tersebut. Tantangan yang menjadi penghambat dalam melestarikan tradisi tersebut di antaranya adalah masalah agama. Seperti yang telah dijelaskan di bagian sebelumnya bahwa dalam sejarahnya, tradisi bakar batu ini pertama kali dilaksanakan oleh umat Kristiani.

Seperti yang telah menjadi rahasia umum bahwa Islam merupakan minoritas di Papua. Lebih dari 90\% penduduk daerah yang dulu dikenal dengan Irian Jaya tersebut adalah Kristen.Dan seperti yang banyak diberitakan oleh media bahwa sering terjadi gesekan antara kelompok Muslim dan umat Kristiani di daerah yang secara geografis terletak di ujung timur Indonesia ini.

Meski dalam sejarahnya sering terjadi gesekan antara kelompok minoritas Muslim dan umat Nasrani, namun Pemerintah Daerah Papua berkomitmen untuk melindungi kegiatan-kegiatan yang dilakukan oleh Komunitas Muslim, termasuk dalam melaksanakan tradisi bakar batu. Bahkan tidak jarang, pejabat setempat ikut memeriahkan acara yang biasanya digelar setiap tahun tersebut.

Adapun tantangan yang menjadi penghambat dalam melaksanakan pelestarian kesenian tradisional di antaranya adalah globalisasi. Dunia globalisasi telah mengubah cara pandang masyarakat pendukung kesenian tradisional terhadap keberadaan kesenian tradisional itu sendiri. Ia tidak hanya disikapi sebagai identitas kultural yang mengakomodasi tuntutan ritual masyarakat pendukungnya saja, kesenian tradisional saat ini juga dituntut menjadi komoditi hiburan yang memuat unsur komersial. Keberadaan kesenian tradisional di era globalisasi ekonomi saat ini berada pada benturan antara nilai tradisional yang mengabdi pada harmoni, keselarasan, dan mistis dengan nilai-nilai kontemporer yang cenderung diorganisasi oleh perkembangan teknologi informasi, konsumsi budaya, dan permintaan media massa. ${ }^{19}$

Karena itu, media massa memiliki tugas dan kewajiban, selain menjadi sarana dan prasarana komunikasi, untuk mengakomodasi segala jenis isi dunia dan peristiwa-peristiwa di dunia ini melalui pemberitaan atau publikasinya dalam aneka wujud seperti berita, laporan penelitian, dan lain sebagainya, dari yang kurang menarik sampai yang sangat menarik, dari yang tidak menyenangkan sampai yang sangat menyenangkan tanpa batasan kurun waktu. Oleh karena itu, dalam komunikasi melalui media massa, media massa dan manusia mempunyai hubungan saling ketergantungan dan membutuhkan karena masing-masing

19 Agus Maladi Irianto, Kesenian Tradisional sebagai Sarana Strategi Kebudayaan di Tengah Diterminasi Teknologi Komunikasi, NUSA, Vol. 12 No. 1 Februari 2017 (Semarang: Universitas Diponegoro), hlm. 91. 
saling mempunyai kepentingan dan memerlukan. ${ }^{20}$ Media massa membutuhkan berita dan informasi untuk publikasinya baik untuk kepentingan media itu sendiri maupun untuk kepentingan orang atau institusi lainnya. Di lain pihak, manusia membutuhkan adanya pemberitaan dan publikasi untuk kepentingankepentingan tertentu.

Selain itu, perubahan sosial menjadi tantangan tersendiri bagi para pelaku seni dan Pemerintah Papua yang menghambat dalam pelestarian kesenian tradisional. Perubahan sosial adalah perubahan yang terjadi sebagai suatu variasi dari cara hidup yang telah diterima karena adanya perubahan kondisi geografi, budaya, komposisi penduduk, ideologi, maupun adanya difusi atau penemuan-penemuan baru dalam masyarakat. Perubahan budaya yang terjadi pada masyarakat sekarang, yaitu perubahan dari masyarakat tertutup menjadi masyarakat yang lebih terbuka. Ilmu pengetahuan dan teknologi telah mengubah dunia secara mendasar. Komunikasi dan sarana transportasi internasional telah menghilangkan batas-batas budaya setiap bangsa. ${ }^{21}$ Peristiwa transkultural seperti mau tidak mau akan berpengaruh terhadap keberadaan kesenian Papua.

Meski terdapat rintangan yang menjadi penghampat dalam pelestarian kesenian tradisional Papua, namun dari hasil penelitian yang dilakukan, ada beberapa faktor yang mendukung dalam pelestarian kesenian tradisional tersebut, di antaranya adalah pemerintah. Salah satu faktor pendukung yang mempengaruhi pelestarian kesenian tradisional adalah peran dari pemerintah baik pusat maupun daerah.

Pemerintah melibatkan masyarakat setempat (warga masyarakat Papua) dalam upaya melestarikan dan mengembangkan kesenian tradisionan dan pengembangan wisata (budaya). Dalam hal ini, pemerintah memberikan kesempatan yang sama kepada masyarakat dan komunitas (sanggar-sanggar kesenian) setempat untuk berpartisipasi dalam pengelolaan dan pengembangan wisata budaya, sehingga masyarakat setempat tidak hanya dapat meningkatkan kesejahteraannya namun secara tidak langsung masyarakat juga dilibatkan dalam upaya melestarikan kesenian tradisional tersebut. Salah satu bentuk dukungan dari pemerintah terhadap berbagai kelompok (sanggar) seni dapat dilakukan dengan cara melibatkan mereka dalam pendataan, inventarisasi,

20 Iko Monika, Kebijakan Pemerintah Daerah dalam Pelestarian Kesenian Tradisional di Kota Makassar, hlm. 93.

${ }^{21}$ Ibid., hlm. 94. 
Millatī, Journal of Islamic Studies and Humanities, Vol. 3, No. 2, Des. 2018: 209-225

pendokumentasian, pengembangan seni budaya tradisional. ${ }^{22}$

Faktor pendukung selanjutnya dalam upaya pelestarian kesenian tradisioanal adalah masyarakat.Pelestarian kebudayaan pada dasarnya bukan semata-mata menjadi kepentingan dan tanggung jawab pemerintah, tapi juga kewajiban semua lapisan masyarakat. Keterlibatan masyarakat dan para anggota atau pelaku seni mutlak diperlukan dalam upaya pelestarian seni budaya. Pemerintah juga perlu memberi kebebasan dan pengawasan terhadap masyarakat dalam mengembangkan seni budaya tradisional yang dimiliki oleh masyarakat. ${ }^{23}$

Peran masyarakat memang sangat dibutuhkan dan memiliki pengaruh yang sangat besar dalam upaya melestarikan kesenian tradisional.Sebab pemerintah pusat maupun daerah tidak akan berjalan dengan maksimal tanpa keterlibatan atau peran aktif masyarakat dan seluruh stakeholder.

Pelestarian kebudayaan (kesenian tradisional) harus diperjuangkan oleh masyarakat luas. Pelestarian kebudayaan dalam suatu masyarakat akan tetap bertahan dengan adanya dukungan dari masyarakat pemilik kebudayaan tersebut. Kebudayaan yang dilestarikan tersebut kemudian dapat dinikmati oleh generasi selanjutnya.

\section{Kesimpulan}

Undang-undang Nomor 21 Tahun 2001 yang menyebutkan otonomi khusus bagi Provinsi Papua. Undang-undang ini pada dasarnya adalah pemberian kewenangan yang lebih luas bagi provinsi dan rakyat Papua untuk mengatur dan mengurus diri sendiri di dalam kerangka Negara Kesatuan Republik Indonesia. Kewenangan yang lebih luas berarti pula tanggung jawab yang lebih besar bagi provinsi dan rakyat Papua untuk menyelenggarakan pemerintahan dan mengatur pemanfaatan kekayaan alam di Provinsi Papua untuk sebesar-besarnya kemakmuran rakyat Papua sebagai bagian dari rakyat Indonesia sesuai dengan peraturan perundang-undangan. Kewenangan ini juga berarti pemberdayaan dan pelestarian tradisi kebudayan Papua.

Namun demikian, kebijakan Pemerintah Papua tersebut bukan hanya berlaku bagi tradisi-tradisi kebudayaan yang berpotensi mendongkrak pariwisata

${ }^{22} \mathrm{Ibid}$.

${ }^{23}$ Muchamad Chayrul Umam, Upaya Pelestarian Kesenian Kenanthi di Dusun Singosari, Desa Sidoagung, Kecamatan Tempuran, Kabupaten Magelang, Skripsi (Yogyakarta: Universitas Negeri Yogyakarta, 2014), hlm. 2. 
Papua, seperti kesenian tradisional yang sudah dikenal oleh khalayak, seperti tari-tarian, seni ukir suku Asmat, festival, budaya, dan lainnya. Tapi tradisi yang masih dilakukan atau dilestarikan oleh kelompok minoritas juga tidak lepas dari peran Pemda Papua melalui dinas kebudayaan dan pariwisata melestarikan tradisi tersebut. Salah satu tradisi yang masih bertahan dan dilestarikan tersebut adalah tradisi bakar batu yang masih dilakukan, dipertahankan, dan dilestarikan oleh Komunitas Muslim di Papua.

Tradisi bakar batu merupakan salah satu tradisi penting di Papua yang berupa ritual memasak bersama-sama warga satu kampung yang bertujuan untuk bersyukur, bersilaturahim (mengumpulkan sanak saudara dan kerabat, menyambut kebahagiaan (kelahiran, perkawinan adat, penobatan kepala suku), atau untuk mengumpulkan prajurit untuk berperang. Dalam tradisi asal, tradisi bakar batu menggunakan daging babi, namun karena ini dilaksanakan oleh warga Muslim Papua, maka daging babi tersebut diganti dengan daging ayam.

Namun, Pemerintah Daerah Papua dan Komunitas Muslim dalam melaksanakan pelestarian tradisi bakar batu tersebut mendapatkan banyak sekali hambatan. Tantangan yang menjadi penghambat dalam melestarikan tradisi tersebut di antaranya adalah masalah agama. Sebab, pada mulanya tradisi ini biasa dilaksanakan oleh non-Muslim dan dalam sejarahnya, tidak jarang terjadi gesekan antara warga Muslim dengan umat Kristiani.Tapi Pemerintah Daerah Papua berkomitmen untuk melindungi kegiatan-kegiatan yang dilakukan oleh Komunitas Muslim, termasuk dalam melaksanakan tradisi bakar batu.

Selain tradisi bakar batu yang dilakukan oleh Komunitas Muslim, Pemerintah Daerah Papua juga melindungi dan melestarikan tradisi atau kebudayaan lain melalui kebijakan-kebijakannya yang tercermin dalam beberapa kegiatan seni budaya, seperti festival budaya yang diselenggarakan setiap tahun, pemberdayaan kesenian tradisional melalui sanggar-sanggar kesenian, dan lain sebagainya. Selain itu juga membangun gedung pusat seni dan budaya, taman budaya, museum, dan lainnya.

Namun demikian, seperti tradisi bakar batu Muslim, Pemerintah Daerah Papua dalam melaksanakan pelestarian kesenian tradisionaljuga tidak berjalan mulus.Adapun tantangan yang menjadi penghambat dalam melaksanakan pelestarian kesenian tradisional di antaranya adalah tuntutan dunia global dan perubahan sosial, yaitu perubahan yang terjadi sebagai suatu variasi dari cara hidup yang telah diterima karena adanya perubahan kondisi geografi, budaya, komposisi penduduk, ideologi, maupun adanya difusi atau penemuan-penemuan baru dalam masyarakat. 
Millatī, Journal of Islamic Studies and Humanities, Vol. 3, No. 2, Des. 2018: 209-225

Meski terdapat rintangan yang menjadi penghampat dalam pelestarian kesenian tradisional Papua, namun ada beberapa faktor pendukung dalam pelestarian kesenian tradisional tersebut, yaitu dukungan pemerintah dan peran aktif masyarakat. Peran masyarakat memang sangat dibutuhkan dan memiliki pengaruh yang sangat besar. Sebab pemerintah pusat maupun daerah tidak akan berjalan dengan maksimal tanpa keterlibatan atau peran aktif masyarakat dan seluruh stakeholder.

\section{Daftar Pustaka}

Agustino, Leo. 2008. Dasar-dasar Kebijakan Publik. Bandung: Alfabeta.

Irianto, Agus Maladi. 2005. Tayub: Antara Ritualitas dan Sensualitas: Erotika Petani Jawa Menuju Dewi. Semarang: Lengkongcilik Press.

.. 2017. Kesenian Tradisional sebagai Sarana Strategi Kebudayaan di Tengah Diterminasi Teknologi Komunikasi, NUSA, Vol. 12 No. 1 Februari. Semarang: Universitas Diponegoro.

Monika, Iko. 2011. Kebijakan Pemerintah Daerah dalam Pelestarian Kesenian Tradisional di Kota Makassar, Jurnal Government, Volume IV, No. 2, Juli 2011. Makassar: Universitas Hasanuddin.

Pereira, C. 2017. Religious Dances and Tourisme: Perceptions of The 'Tribal' as the Repository of the Tradisional in Goa, India. Etnografica. Revista do Centro em Rede de Investigacao em Antropologia, 21.

Rismansyah, Nurdin. 2014. Perancangan pusat seni tradisi Sunda di Ciamis Jawa Barat: Tema reinterpreting tradition, Tesis. Malang: UIN Maulana Malik Ibrahim.

Rumansa. 2003. Peran Sanggar Seni dalam Menunjang Kegiatan Bimbingan Edukatif pada Pameran Benda Budaya Koleksi Museum-museum di Papua, Jurnal Antropologi Papua, Vol. 1, No. 1, 3 April.

. 2014. Inventarisasi dan Verifikasi Karya Budaya Seni Ukir Asmat. Yogyakarta: Kepel Press.

. 2015. Memahami Kebudayaan Lokal Papua: Suatu Pendekatan Pembangunan yang Manusiawi di Tanah Papua, Jurnal Ekologi Birokrasi, Vol. 1, No. 1, Februari. Jayapura: Universitas Cenderawasih.

Salma, Irfa'ina Rohana dkk. 2017. Piranti Tradisi dalam Kreasi Batik Papua, Dinamika Kerajinan dan Batik, Vol. 34, No. 2, Desember.

Soekanto, Soerjono. 2007. Pengantar Penelitian Hukum. Jakarta: UI Press. 
Suroto, Hari. 2009. Pelestarian Sumberdaya Budaya dalam Bingkai Otonomi Khusus Papua, Jurnal Papua Vol. 1 Nomor 1, Juni.

Tangkilisan, Hessel Nogi S. 2003. Evaluasi Kebijakan Publik: Penjelasan, Analisa, dan Transformasi Pikiran Nagel. Yogyakarta: Balairung.

Umam, Muchamad Chayrul. 2014. Upaya Pelestarian Kesenian Kenanthi di Dusun Singosari, Desa Sidoagung, Kecamatan Tempuran, Kabupaten Magelang, Skripsi. Yogyakarta: Universitas Negeri Yogyakarta.

Undang-undang No. 21 Tahun 2001 tentang Otonomi Khusus bagi Provinsi Papua.

Wahab, Solichin Abdul. 2008. Analisis Kebijakan Publik: Dari Formulasi ke Implementasi Kebijakan Negara (edisi 2). Jakarta: Bumi Aksara.

William, R. 1981. Culture. London: Fontana.

Winarno, Budi. 2002. Kebijakan Publik: Teori dan Proses. Yogyakarta: Media Presindo.

\section{Website:}

Dian Afrilia, Festival Budaya Asmat dan Lembah Baliem di Papua, www.beritatagar.id Festival Lembah Baliem yang Mendunia”, https://ekonomi.kompas. $\mathrm{com} / \mathrm{read} / 2015 / 08 / 21 / 101600927 /$ Festival.Lembah.Baliem.yang. Mendunia?page $=$ all

https://id.wikipedia.org/wiki/Bakar_Batu

http://media.isnet.org/

www.citranashwatour.com

www.kompasiana.com 
